\title{
Teaching Indonesian as Foreign Language in Indonesia: Impact of Professional Managerial on Process and Student Outcomes
}

\author{
Kundharu Saddhono \\ Universitas Sebelas Maret \\ Surakarta, Indonesia \\ kundharu.uns@gmail.com
}

\begin{abstract}
Indonesian language has now become a part of popular languages in the world. Therefore it is a need to be an effort for learning Indonesian language for foreign speakers can be performed well. To conduct the learning process properly, professional management is needed. BIPA program management consists of various aspects; both of the BIPA program organizers, students, faculty, and other supporting aspects. The study on BIPA program managers was conducted in 10 provinces in Indonesia, namely Padang, Medan, Jakarta, Bandung, Solo, Malang, Denpasar, Lombok, Makassar and Banjarmasin. The results of the study show that professional and integrated management will produce satisfactory results. Foreign students quickly master Indonesian language due to good and right professional management. The management related to the learning process is organized in BIPA program. Of course, a series of learning activities and cultural practices also become an integral part in the process of mastering their language competence and learning Indonesian culture. Thus the organization of BIPA program will be more professional and its performance can be measured properly.
\end{abstract}

Keywords- Teaching Indonesian as Foreign Language, Professional Managerial, Student Outcomes, Indonesian Culture

\section{INTRODUCTION}

Since it is established as national language in Sumpah Pemuda (The National Youth Oath), 28 October 1928, and determined as country language in the Constitution verse 36, Indonesian language has been rapidly developing. The development has been made Indonesian language as the symbol of nation's identity and as a unifying device of many ethnic groups with their own social backgrounds, cultures, beliefs, and local languages. In addition, Indonesian language has also fulfilled its function as modern communication device in governmental implementation, education, and science, technology and art development. [1]

Bahasa Indonesia bagi Penutur Asing (BIPA) or Teaching Indonesian as Foreign Language in Indonesia (in English), in the past few years, becomes an interesting topic. [2] Foreign countries, especially Economic Community, are racing to study Indonesian language in order to face Asean Economic Community (AEC). Indonesia is the greatest market segment due to Indonesians' consumptive culture. However, AEC is agreed and Indonesian people should prepare themselves to face free market.

In relation to that issue, Indonesian language is being taught to foreigners in many institutions, both in Indonesia and overseas. In Indonesia, there are not less than 45 institutions teaching Indonesian language for foreigners, whether they are in Universities or language course institutions. In the other hand, outside Indonesia, BIPA has been being taught in about 36 countries in the world with not less than 130 institutions consisting of universities, foreign cultural centers, Republic Indonesia Embassy, and language course institutions.

The proposed curriculum in international conference of BIPA IV classified the purpose of studying Indonesian language into two objectives; (1) General Objectives: BIPA students understand that Indonesian language as national identity symbol of Indonesia, BIPA students understand Indonesian language linguistically (pronunciation, phonology, morphology, syntax, and vocabulary), BIPA students are able to use Indonesian language according to its style receptively and productively, and BIPA students are able to appreciate Indonesian literature and its types (prose, poem, drama, song lyric). (2) Particular Objectives: being able to pronounce word and sentence properly with proper intonation that fits its meaning, being able to use standardized orthographic Indonesian language, being able to use various prefix, suffix, and infix according to its meaning properly, being able to use words according to its meaning, being able to get and use synonym, antonym, and homonym, being able to understand that same form can have more than one meanings, being able to know and enjoy poem, prose, and Indonesian drama, being able to accept message and feeling from others and then respond it in oral and written form, being able to express feeling, opinion, dream, and experience in oral and written form depending on its media, being able to interact and have relationship with others orally depending on the situation, and being able to enjoy and capture the message contained in poem, prose, drama, and song lyric. [3]

\section{RESEARCH METHODOLOGY}

This research is descriptive qualitative; analyzing data about the interest of foreign university students who study Indonesian language through BIPA program held by 12 universities and language centers in Indonesia together with their organizers. The data of this research was gained from literature review, observation, and interview with BIPA organizer in every university where BIPA is implemented. Events, event settings, and interview results were gained by conducting purposive sampling technique. After the data were 
collected, the data were then validated using triangulation. Triangulation is process of checking data credibility by using several data collection technique and several sources of data. [4] This triangulation technique is divided into three types; triangulation with source, triangulation with method, and triangulation with theory. [5]

\section{FINDINGS AND DISCUSSION}

BIPA program in Sebelas Maret University is under the management of International Office (IO) UNS. However, the learning implementation is under UPT P2B (UNS Language Center). Historically, BIPA learning process in UNS started in academic year 2010-2011. Its first class was on October 2010. For now, BIPA students are all foreign students of UNS registered in every academic year through all channels and scholarship including those who are candidate of post-graduate students. The students are classified based on special selection by UNS Team and Developing Countries Partnership scholarship. Furthermore, BIPA teaching staffs in UNS are Indonesian language lecturers from Faculty of Teaching and Education and from Faculty of Language and Culture. In addition, BIPA learning program has already used cultural aspect consistently. The lecturers also always increase innovative learning process as teaching. [6] It can be seen from BIPA activities in UNS which are coordinated by International Office. There are Goes to the Village and Cultural Night as the medium to introduce different cultures of several countries involved. BIPA in UNS has also had its learning material which is improved and published by UNS Language Center. Yet there are still revisions needed. BIPA learning mechanism in UNS under UNS Language Center are described as follows: (1) Simple pre-test on Indonesian language competence, (2) Teaching and learning implementation in 6 levels (BIPA for Beginner I-IV and BIPA for Academic Purposes I-II), (3) Each level takes 22 meetings; 90 minutes per meeting, (4) Each level includes 8 times face-to-face tutorials (2x @ 90 minutes per week) which are in the form of outdoor activities supervised by the tutor in order to deepen the students' competence in Indonesian language by having conversation on several topics, (5) proficiency post-test officially known as the Test of Indonesian as a Foreign Language (TOIFL) from the Language Center.

BIPA learning in UNS is divided into several major levels. Firstly, Beginner Level (Beginner I-IV) which gives basic introduction to Indonesian language, language threshold competence, and four basic language competences (writing, reading, observing, and speaking). Secondly, Academic Level (Academic I-II) which prepares foreign students to be able to use Indonesian language in academic purposes; to be able to use four language competences altogether in receiving information from classes, writing papers, presenting, and absorbing information from textbooks.

BIPA program in Indonesia University of Educatioan (UPI) is under the management of Universitas Pendidikan Indonesia Language Center and is available on www.bipaupi.org. BIPA students in UPI are from Korea, Japan, Thailand, and other countries. As it is in other universities, BIPA program in UPI refers to university's Language Center regulations. They apply innovative teaching and learning methods. It is related to a study conducted by Korean student. [7] In the implementation, there is specific characteristic in the management of UPI's BIPA. The uniqueness of BIPA program in UPI is on the regulation of Balai Bahasa UPI that sends all BIPA students to study in the Department of Indonesian Language and Literature under the Faculty of Language and Arts in UPI. The regulation aims to help BIPA students to study the language directly by having direct interaction with Indonesian native speakers (lecturers and native students). By doing this, BIPA students in UPI will be able to improve their Indonesian language competence.

BIPA program in State University of Malang (UM) is under the management of Language and Culture Center Faculty of Literature, UM. Annual program proposal, syllabus, teaching material, learning method, learning implementation, and learning evaluation are proposed by Language and Culture Center UM. [8] BIPA students of UM are also various like those who study in other universities. Not only from scholarship students, BIPA students in UM are also from Developing Countries Partnership Scholarship and independent class which are directly managed by Language and Culture Center UM. By having that kind of management, they hope that BIPA program is centered and can be controlled well. While BIPA program's teachers are not only those who have Indonesian language educational background, but also those who come from departments other than Indonesian Language Department.

BIPA program in Udayana University is under the management Udayana University Language and Culture Center and is available on http://bipaunud.org. BIPA students of Udayana University come from Korea, Japan, Thailand, Rusia, and some other countries due to Bali's image as the destination of 'adventurer' from abroad including those who do not come only for tourism interest. BIPA program implementation also refers to the National Language Center regulation even there are some improvements in learning implementation aspect focusing on tourism and local Balinese culture. In its learning implementation, the uniqueness is on outdoor activities done by BIPA students. They interact directly with Balinese people by using Indonesian language.

Generally, BIPA implementation in UNP is not running well. It is because of its unclear management which is handled by Indonesian Language Department of UNP. Moreover there is interference from foreign party, Australia. It can be seen from http://www.unp.ac.id/node/654/feed-items that BIPA program in UNP partners with Deakin University, Australia. All of BIPA learning tools such as curriculum, syllabus, and teaching material are all prepared by Deakin University. There is also local culture content integrated in all teaching and learning tools. However, there are some better improvements needed both in the BIPA program management and its teaching material.

BIPA in North Sumatra is managed by Special Division of BIPA which conducts BIPA holistically for foreign students and is available on http://balaibahasa- 
sumut.com/index.php/layanan/bipa.html. Based on observation in North Sumatra, it is understood that BIPA program implementation is handled directly by North Sumatra Province Language Center. The implementation is conducted by partnering with Universitas Sumatera Utara. Concretely, all BIPA students are encouraged to go to North Sumatera Language Center to study Indonesian language. The teachers use good teaching materials. It is well arranged and easy to understand. It also contains local culture values which make BIPA program implementation become more interesting.

BIPA program in Universitas Negeri Makassar (UNM) is under the management of UNM Language Center which has a special division to take a good care and manage BIPA program. It can be said that the management of BIPA in UNM is good. Its learning method is also innovative. [9] It is indicated by management system which is directly handled by Language Center so that the materials they use are well standardized. Teaching staffs in this program also have good competence, both theoretically and practically. Globally, the data gained from BIPA program in UNM points out that this program is implemented well and they have good teaching materials. Special thing on the implementation of BIPA program in UNM is on the dominancy of teaching staffs from English Teaching Department. However, this phenomenon does not distract learning process because they share same basic knowledge about linguistics.

BIPA in Lambung Mangkurat University is under the management of Universitas Lambung Mangkurat Banjarmasin International Office (IO). Mono-teaching-staffs are lecturers from Department of Indonesian Language Studies so the implementation of BIPA is directly handled by this department. BIPA program in Lambung Mangkurat University shows that it is not good enough. It is seen from the facts that BIPA learning process is sporadic. It is also unwell conditioned. Moreover, teaching materials and curriculum for BIPA program are still adopted another program. Furthermore, there is lack of scientific approach in conducting BIPA which becomes a barrier in its implementation.

BIPA in Unismuh Makassar is under the management of International Office (IO). Generally, BIPA program in Unismuh Makassar runs well. It has teaching materials from Language Center. The materials consist of eight modules which can be accessed via online and printed. It has actual and factual contents. One of the constraints of BIPA program in Unismuh Makassar is on its little number of BIPA students; about 10 students per year. Furthermore, BIPA students find it hard to adapt to local culture of Indonesia, especially in terms of their etiquette toward people.

BIPA program in Universitas Indonesia (UI) is under the management of International Language Center of the Faculty of Language and Culture UI. BIPA students in UI are from Korea, Japan, Thailand, Rusia and other countries. The implementation of BIPA program in UI aims at academic purposes. The objectives of BIPA manager in UI are to prepare BIPA students to study in UI, to work in Indonesia, and in specific purpose such as to marry Indonesian and live in Indonesia as housewife, for instance, etc. The final purpose of
BIPA program is that they will have Indonesian language competence. On the other hand, BIPA program in UI also opens special program which is adjusted to market needs on learning Indonesian language.

Regular program is conducted within 16 weeks, from January to May and August to December. This program is done in one year. In class meetings are 15 hours per week, on Monday to Friday, at $09.00 \mathrm{am}-12.15 \mathrm{pm}$. There is also outing class for regular program. It is one day field experience trip to visit several places around UI and even outside Java Island. This outing class can be conducted in schools, Taman Mini Indonesia Indah, TV stations, factories, prisons, or government offices. This activity aims to train BIPA students in beginner level and to give them opportunity to practice Indonesian language directly with local people.

BIPA program in UI consists of three levels; (10 Elementary (BIPA I), in this beginner level, the students will practice conversation every day, they also learn about Indonesian culture so that this cultural knowledge will deepen their communication skill using Indonesian language in many contexts; (2) intermediate (BIPA II), in relation to the main objective of studying Indonesian language in terms of speaking and writing competences using Indonesian language properly. In order to achieve these competences, learning process will be conducted through discussion, verbal presentation, and descriptive writing methods; (3) advance (BIPA III) will empower students to be able to involve in discussion and writing essay about several topics related to Indonesian people and culture, law issues of Indonesia, Indonesian politics, and Indonesian economy condition.

The implementation of BIPA in UI is conducted in a discipline way. It can be seen from the developing curriculum according to the developing eras and heterogeneous BIPA students. In addition, teaching materials which are prepared based on students' needs and the four Indonesian language basic competences. Further, the implementation of BIPA is conducted on time and the students are enthusiastically joining different classes based on the school arrangement. In class, the students have their academic supervisor so they can consult their academic supervisor and ask for a help in relation to Indonesian language studies. There will be a punishment for those students who do not follow the rules and rarely join the classes affecting their staying permit in Indonesia because UI Language Center also partners with Indonesian Immigration office.

BIPA program of UI also has extracurricular activities which help to ease the students in learning Indonesian language. By joining BIPA program of UI, the students not only study about language, but they also join beneficial extracurricular activities such as traditional music class, dancing class, and batik painting class. These activities are conducted in the evenings. In traditional music class, the students will learn traditional songs in the local dialect and popular songs in Indonesian language. In dancing class, the students will learn to dance traditional dances from one of Indonesian areas. In batik painting class, the students not only learn about basic principal of the making of traditional batik 
clothes, but they also experience the process of making batik themselves and make their own batik clothes. In the end of fiscal year, the students also have the opportunity to perform their skills in BIPA graduation ceremony. This graduation ceremony can be media for the students to perform their creativities and skills to acculturate Indonesian culture on them. In other words, everyone who comes to this graduation witnessed the students' achievements.

BIPA in Universitas Negeri Jakarta (UNJ) is under the management of Its International Office (IO). The teaching staffs of BIPA in UNJ are varies and majority from Indonesian language Department. BIPA implementation in UNJ generally runs well. Many studies has been conducted in relation to BIPA teaching materials in UNJ. [10] It is indicated by the achievement of the students that they are able to communicate in Indonesian language after joining one semester of BIPA class even it is conducted in big class. In addition, BIPA learning process is also conducted specifically. It can facilitate all students according to placement test result, even there are only little number of students in one class. The materials used in BIPA program has been in line with Common European Framework of Reference (CEFR) which is adjusted to the field needs. BIPA program in UNJ also has its uniqueness; BIPA for elementary students in Taipei School. However, in its implementation in Taipei School, there is still some constraints in terms of Indonesian language acquisition because they do not use Indonesian language in their daily conversation.

In West Timor Language Center, there is an organization named Malfi. It stands for Mataram Lingua Franca Indonesia located in Language Center. Other than in Language Center, there is also BIPA program conducted in Nyumun. BIPA learning program in Nyumun is categorized into two learning categories; Indonesian language for foreign workers and national language for local workers. Teaching and learning process is conducted based on 2013 curriculum and is integrated to local culture. BIPA in West Timor Language Center has problem dealing with limited teaching staffs. There are only six teachers. Moreover, the teaching materials are hard to digest by the students due to its high level of language used and inconsistency.

\section{CONCLUSION}

BIPA implementation in several universities in Indonesia has been running well and systematically based on learning system applied on each university. However there are some parts of the implementation which need to be given more attention and to be investigated deeper in terms of its management, teaching staffs, and teaching materials used. Considering the main objective of BIPA that BIPA students suppose to master four basic competences in terms of using Indonesian language correctly and properly. It can be seen that there are three levels of learning Indonesian language for BIPA students. The class leveling system aims to introduce Indonesian language from the very basic or simple one into the complex one so that the BIPA students have the skills of using Indonesian language correctly and properly in their daily lives and in public forum. Ideally, BIPA program is managed specifically by language based organization and is not managed by university department or International Office. In addition, BIPA learning program which integrates culture and language in the learning process done by some universities in Indonesia are adding students' knowledge about local culture as they study the language. Furthermore, there are cultural nights in the end of the year as the closing of BIPA program in several universities in Indonesia.

\section{ACKNOWLEDGMENT}

The author expressed his gratitude to the Indonesian Endowment Fund for Education (LPDP), the Ministry of Finance, the Republic of Indonesia and LPPM Sebelas Maret University for MRG Grant with Contract Number 632/UN27.21/LT/2016

\section{REFERENCES}

[1] Saddhono, Kundharu, "Integrating Culture in Indonesian Language Learning for Foreign Speakers at Indonesian Universities," Journal of Language and Literature, 6 (2) pp. 349-353, 2015.

[2] Rohmadi, Muhammad, Peluang dan Tantangan Pembelajaran Bahasa Indonesia Bagi Penutur Asing (BIPA) di Era Masyarakat Ekonomi Asean (MEA). Konferensi BIPA Tahunan (KEBIPAAN) I, Surakarta 14 Mei 2016.

[3] Iskandarwassid \& Dadang Sunendar, Strategi Pembelajaran Bahasa, Bandung: Rosda, 2011.

[4] Sugiyono, Metode Penelitian Kuantitatif Kualitatif \& RND, Bandung: Alfabeta, 2010.

[5] Moleong, Lexy J, Metodologi Penelitian Kualitatif, Bandung: Remaja Rosdakarya, 2004.

[6] Saddhono, Kundharu. The Argumentative Writing Skill with Multicultural Awareness in Indonesian Language for Foreign Learners. Ponte: International Scientific Researches Journal 72(4): pp. 108-116, 2016

[7] Taftiawati, Meida, "Strategi Komunikasi Pembelajar BIPA UPI Asal Korea Selatan dalam Pembelajaran BIPA Tingkat Dasar,", Pembelajaran BIPA, (1), 2014.

[8] Azizah, Rifca Farih; Hs., Widodo; and Lestari, Ida. Pembelajaran Bahasa Indonesia Bagi Penutur Asing (BIPA) Program CLS (Critical Language Scholarship) di Fakultas Sastra Universitas Negeri Malang Tahun 2012. Malang: Malang State University http://jurnalonline.um.ac.id/data/artikel/artikelC8CE6EFA60B873A1B6DB1DC2 OF6CFE40.pdf. 2012

[9] Wartini, N. K.,’Penggunaan Lagu dalam Kelas BIPA,” KIPBIPA Makassar, unpublished, 2004.

[10] Muliastuti, Liliana, Dasar-Dasar Pengajaran Bahasa Indonesia untuk Penutur Asing (BIPA), Jakarta: FBS Universitas Negeri Jakarta, 2011. 